\title{
Physical and Chemical Properties of Silver Rasbora Bekasam Using Various Types of Processed Rice as Fermentation Media
}

\author{
Anugerah Dany Priyanto ${ }^{1}$, Sri Djajati \\ Department of Food Technology \\ Universitas Pembangunan Nasional "Veteran" Jawa Timur \\ Surabaya, Indonesia \\ 1anugerahdany.tp@upnjatim.ac.id
}

\begin{abstract}
The most frequent problem in increasing demand of fishery products is rapidly quality decline of fresh products. Therefore, obligatory right handling is required to maintain the fish quality. Aims of this study was to determine the type of processed rice as fermentation media in silver rasbora bekasam toward the physical and chemical properties. The research was designed by a Completely Randomized Design (CRD) which was only 1 factor. The factor were consisting 4 levels and 1 control with 4 replications, resulting in 20 experimental units. These levels were various types of processed rice (uncooked rice, cooked rice, karak, nasi aking). The data were analyzed using Analysis of Variance (ANOVA) and continued to use Duncan Multiple Range Test (DMRT) at $\alpha=5 \%$. Fermentation of bekasam using various types of processed rice has a significant effect on physical and chemical parameters $(P<\mathbf{0 . 0 5})$. Cooked rice was chosen as the best treatment with the following characteristics: moisture content $(70.75 \pm 1.61 \%)$, pH value $(4.96 \pm 1.76)$, $\mathrm{N}$-Amino $(3.45 \pm$ $0.22 \%)$ and texture $(203.13 \pm 55.15 \mathrm{~N})$.
\end{abstract}

Keywords-bekasam, silver rasbora, fermentation, processed rice

\section{INTRODUCTION}

Indonesia is a maritime country with $2 / 3$ of its parts constituting the sea area [1]. This makes Indonesia potentially strategic as a national economic development. According to the Minister of Maritime Affairs and Fisheries, Indonesia's national fish consumption increased by 1.2 million tons from 2014 to 2016 [2]. Although the level of marine fish contributes more than freshwater, the enhancement of freshwater fish production have to be cultivated in several local aquafarms. The quality decline of fresh fish often occurs when distributing and selling in traditional markets. Therefore, good handling is one of solution with proper processing into processed products. Food processing can maintain quality even improve quality as well as nutritional values such as fermentation. In addition, economically it can also increase the added value.

Bekasam is traditional fish processing which is spontaneously fermented product with the addition of salt and rice. lactic acid bacteria (LAB) grows in bekasam product due to fermentation [3]. Spontaneous fermentation is a microorganism fermentation which naturally contained in these foodstuffs which is commonly used using selective media, such as salt, organic acids, mineral acids, rice or starch. The salt will kill pathogenic and spoilage microorganism. The addition of salt is intentional to stimulate the growth of halotolerant bacteria and LAB. In addition, the source of carbohydrates from rice added will be fermentation media and further fermented into organic acids. In addition, during the fermentation process, there are metabolites as antimicrobial compounds produced from $\mathrm{LAB}$, causing the longer of shelf life time [4].

LAB that grows on bekasam is also classified as amylolytic bacteria. Rice as a source of carbohydrates contains starch which will be the initial substrate for $\mathrm{LAB}$ that are broken down into simple carbohydrates. Some studies use a variety of different carbohydrate sources to explore the best carbohydrate sources in terms of quality characteristics and efficiency of economic value. Some sources of carbohydrates include sticky rice flour, cornmeal, wheat flour, tapioca flour and rice flour which are applied to catfish bekasam [5].

Several researches on raw materials from various types of aquatic products, including seawater, freshwater and brackish water, namely milkfish [6], red tilapia, catfish [5], and squid [7]. As far as we know, bekasam from silver rasbora fish have not been reported previously. This fish is classified as a very abundant freshwater fish. Edible portion of silver rasbora fish is almost all of its parts can be eaten.

The economic value of silver rasbora fish is not higher than the other freshwater fishes. Therefore, it is necessary to conduct research on bekasam from silver rasbora fish. The study observed the effect of various types of processed rice, because the origin of these traditional foods was processed using rice. This research focuses on various kinds of processed rice such as uncooked rice, cooked rice, karak and nasi aking as sources of starch that will be used as energy by microorganisms. Hopefully, this research provides a scientific study on the diversification of bekasam products that use raw materials with a wider surface area (small size) compared to other fishes. In addition, this research is expected to increase the added value of physical and chemical properties. 


\section{MATERIALS AND METHODS}

\section{A. Experimental Design}

The research was carried out in three stages, namely raw material analysis, production of silver rasbora bekasam and bekasam analysis. The research design was observed using a Completely Randomized Design (CRD). Various types of processed rice, such as uncooked rice, cooked rice, karak, nasi aking were used to develop the research as fermentation media. The observed products were consisting 4 different bekasam and 1 fresh fish as control. It has 4 replications to analyse the parameters, resulting in 20 experimental units.

\section{B. Production of Silver Rasbora Bekasam}

Fresh silver rasbora fish were washed using flowing water, weighed and recorded the weight. Various types of processed rice (uncooked rice, cooked rice, karak, and nasi aking) and salt based on the experimental design was added in fres silver rasbora fish. The weight of processed rice and salt were calculated $50 \%$ and $10 \%$ from the weight of fish, respectively. The blended of fish, processed rice and salt were mixed until homogeneous on the entire surface of the fish body. The homogeneous materials were placed in each jar with the different labeled code. The jars were tightly closed for 7 days to give the fermentation time.

\section{Physical and Chemical Analysis of Raw Material and Bekasam}

The tested parameters of raw material were $\mathrm{N}$-amino, moisture content, $\mathrm{pH}$ value, and texture (hardness). The body of fish were separated from processed rice as carbohydrate sources, then the solid part of fish were analyzed with the same several parameters with raw material.

\section{Statistical Analysis}

The experiment data were calculated using Analysis of Variance (ANOVA) and continued to use Duncan Multiple Range Test (DMRT) at $\alpha=5 \%$.

\section{RESULT AND DISCUSSION}

\section{A. Moisture Content Properties}

The results of the study showed different levels of moisture content for each treatment (Fig 1). The analysis of variance on moisture content showed that significantly different. The highest moisture content in the control was $81.49 \pm 0.44 \%$. The control was fresh fish that have not been fermented. During the fermentation process will produce more moisture content. Salt will produce more controlled fermentation conditions. Therefore, the only halophilic microorganisms can survive. These microorganisms are capable to produce proteolytic enzymes. The protease will break down proteins into amino acids, especially glutamic acid which is vegetated in the formation of savory flavors in food [8].

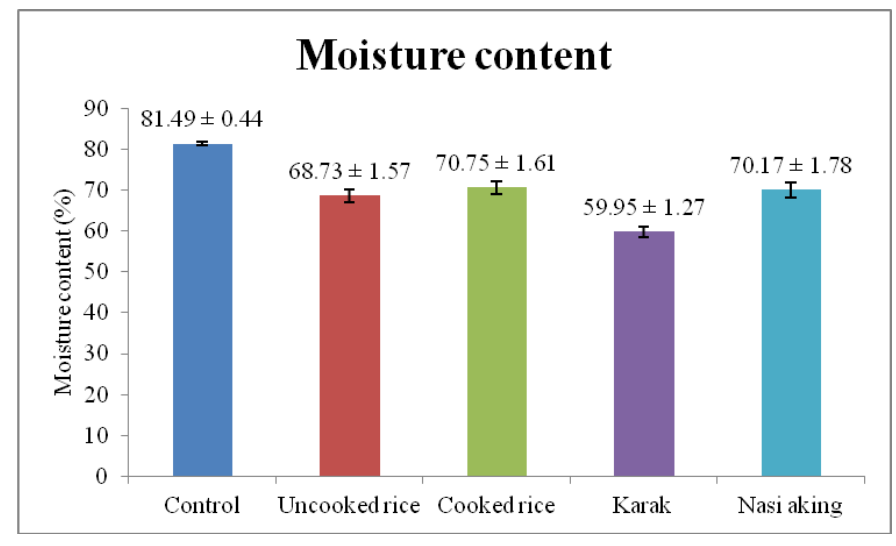

Fig. 1. Moisture content properties of silver rasbora bekasam with different processed rice. Error bars indicate standard error.

Bacterial growth due to biochemical activities in bekasam. Lower levels of moisture content caused by microorganisms activities. Those things can be verified by the difference in moisture content between fresh fish and bekasam products. In addition, the data on cooked rice and nasi aking was the higher moisture content than uncooked rice and karak. This is related to the sources of carbohydrates that are easy to absorb the water and have not been retrograded starch [9]. Therefore, the water binding can be maintained in the material.

\section{B. Acidity Properties}

The originally processing of bekasam still utilizes traditional method with the application of spontaneous fermentation. The fermentation process is carried out in the jar to prevent contamination and a period of 5 to 7 days. Lactic acid bacteria that grow on the product will break down starch and ferment into simple compounds, such as lactic acid, acetic acid, propionic acid, and ethyl alcohol. These compounds are useful as preservatives and sour taste in products. The ANOVA data of $\mathrm{pH}$ value indicated that significant differences and after further testing using DMRT can be seen in Table 1.

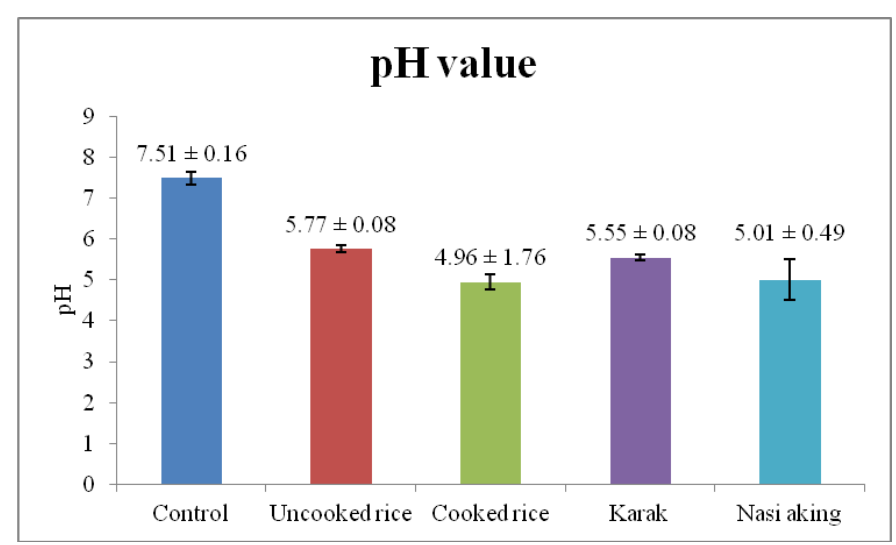

Fig. 2. Acidity properties of silver rasbora bekasam with different processed rice. Error bars indicate standard error.

The $\mathrm{pH}$ value of the experiment showed that the cooked rice as medium of fermentation has the highest acidity. Cooked rice is uncooked rice that is cooked by adding water 
and processed using high temperature, causing the gelatinization of starch [10]. This phenomenon indicates that carbohydrates in rice are easier to degrade when compared to other fermentation media. The ease of carbohydrates degradation makes the high metabolism of microorganisms by fermentation process. Therefore, microorganisms are more optimum to produce metabolites, such as organic acids. Lactic acid bacteria can convert glucose or other hexoses into lactic acid and other acids [11]. These biochemistry reaction resulted the acidity bekasam using cooked rice as the media fermentation was higher than the others.

TABLE I PHYSICAL AND CHEMICAL PROPERTIES OF BEKASAM

\begin{tabular}{|c|c|c|c|c|}
\hline $\begin{array}{c}\text { Souce of } \\
\text { carbodydrates }\end{array}$ & N-Amino (\%) & Moisture content $(\boldsymbol{\%})$ & pH & Hardness (N) \\
\hline Control & $0.73 \pm 0.04 \mathrm{a}$ & $81.49 \pm 0.44 \mathrm{c}$ & $7.51 \pm 0.16 \mathrm{c}$ & $1074.45 \pm 51.66 \mathrm{c}$ \\
Uncooked rice & $1.39 \pm 0.06 \mathrm{~b}$ & $68.73 \pm 1.57 \mathrm{~b}$ & $5.77 \pm 0.08 \mathrm{~b}$ & $347.31 \pm 38.41 \mathrm{~b}$ \\
Cooked rice & $3.45 \pm 0.22 \mathrm{~d}$ & $70.75 \pm 1.61 \mathrm{~b}$ & $4.96 \pm 1.76 \mathrm{a}$ & $203.13 \pm 55.15 \mathrm{a}$ \\
Karak & $1.51 \pm 0.08 \mathrm{~b}$ & $59.95 \pm 1.27 \mathrm{a}$ & $5.55 \pm 0.08 \mathrm{~b}$ & $279.58 \pm 81.99 \mathrm{ab}$ \\
Nasi aking & $2.59 \pm 0.07 \mathrm{c}$ & $70.17 \pm 1.78 \mathrm{~b}$ & $5.01 \pm 0.49 \mathrm{a}$ & $220.96 \pm 57.05 \mathrm{a}$ \\
\hline
\end{tabular}

Significant differences in each row were expressed as different letters $(P<0.05)$.

\section{N-amino Properties}

As shown in Table 1, N-amino levels in all experiments has range from $0.73 \pm 0.04$ to $3.45 \pm 0.22 \%$. After calculating the analysis of variance exhibited significantly different amongst uncooked rice, cooked rice, karak and nasi aking. Namino analysis method is used to measure protein hydrolysis. Proteins are formed from amino acid monomers directly connected by peptide bonds between other amino acids. Namino indicates that the level of protein hydrolysis occurs in fermented products. The high level of $\mathrm{N}$-amino value means high degree of hydrolysis. The biggest value was founded in fermented fish (bekasam) using cooked rice with $\mathrm{N}$-amino value was $3.45 \pm 0,22 \%$.

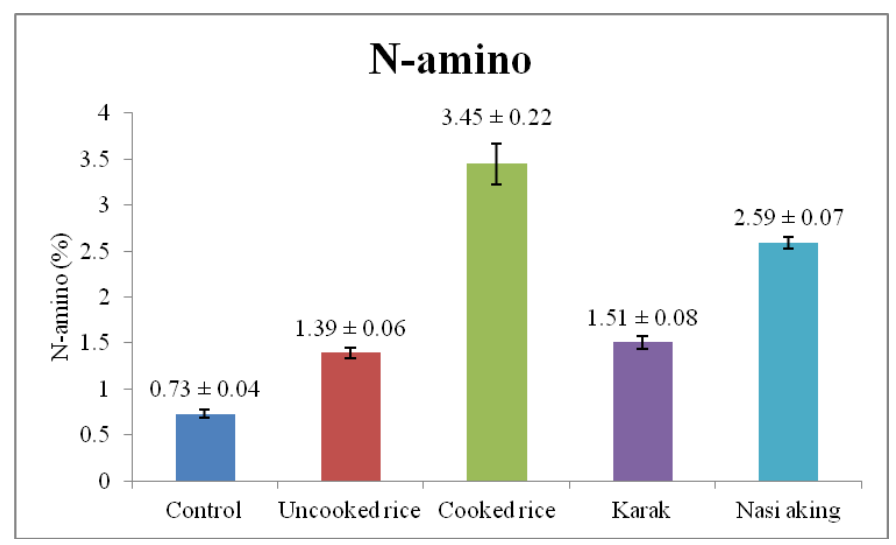

Fig. 3. N-amino properties of silver rasbora bekasam with different processed rice. Error bars indicate standard error.

The level of hydrolysis in this case is influenced by how easily the components are hydrolyzed by microorganisms. The gelatinized starch will be more easily metabolized by microorganisms [12]. Good metabolism will accelerate the growth of biomass from microorganisms which will directly increase its metabolites. This phenomenon will also affect the level of hydrolysis that occurs because microorganisms also uses source of nitrogen. Fish protein contributes as a substrate of microorganisms to be utilized by its nitrogen source. Therefore, the results of hydrolysis of proteins can be seen from how much $\mathrm{N}$-amino is formed.

\section{Textural Properties}

There is a difference amongst fresh fish and all bekasam treatment. It was seen that fresh fish has a hard texture when compared to all bekasam products. This is caused by the fermentation process degrades complex molecules from fish. It also indicates the higher the level of fermentation makes the lower hardness of product. Uncooked rice was the hardest texture bekasam among the others due to the starch granules from uncooked rice have not been broken and gelatinized. The others processed rice as media fermentation were not harder like uncooked rice because the starch granules already broken even though some have experienced retrograde. In this case, the ability to bind water is better than uncooked rice, so it is easier for microorganisms to use the water.

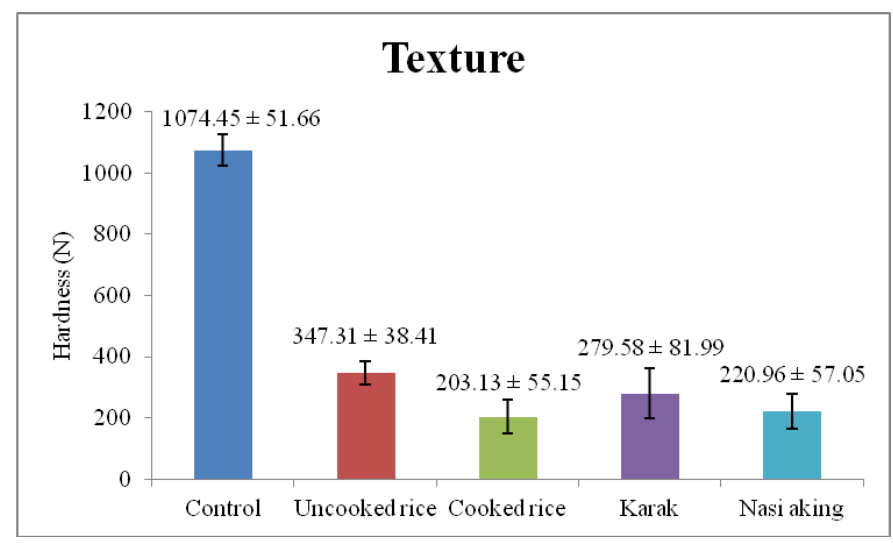

Fig. 4. Textural properties of silver rasbora bekasam with different processed rice. Error bars indicate standard error.

$\mathrm{pH}$ value and texture (hardness) had directly linear data. the $\mathrm{pH}$ value showed the level of fermentation has a high level of acidity as indicated by the low $\mathrm{pH}$ value. Hardness is related to several fish muscle proteins such as myofibril and sarcoplasmic [13]. Generally, protein hydrolysates is produced by acid hydrolysis as a conventional method. Therefore, to cleave the peptide bonds of protein are used strong acid [14]. The fermentation treatment causes protein degradation. Thus, it made the soften tissue in fish. The similarity as shown from previous discussion, the treatment of cooked rice as a fermentation media exhibited a higher level of fermentation than others. The cooked rice has texture parameter of hardness 
which resulted in having the lowest value, specifically 203.13 $\pm 55.15 \mathrm{~N}$.

\section{CONCLUSIONS}

In this study, the best source of carbohydrate to use as fermentation media in fermentation of bekasam was cooked rice. The reason to choose cooked rice as the best fermentation media due to its carbohydrate is easily to breakdown into sugar. It simple monomer can be fermented into many metabolites by selected microorganisms. As shown in data experiment, cooked rice has the best physical and chemical properties of bekasam. As far as we know, this research was the first research to study bekasam using silver rasbora fish as raw material. We believe that the processing of silver rasbora fish into bekasam to improve the quality and extend the shelf life are promising. Hopefully, the further research will focus on microbiological properties and sensory evaluation.

\section{ACKNOWLEDGEMNTS}

This work was financially supported by RISDA (Riset Dasar) grant of LPPM Universitas Pembangunan Nasional "Veteran" Jawa Timur.

\section{REFERENCES}

[1] Ministry of Marine Affairs and Fisheries Republic of Indonesia. Developing Maritime to Restore Glory as Maritime State. http://www.ppk-kp3k.kkp.go.id/ver2/news/read/115/membangunkelautan-untuk-mengembalikan-kejayaan-sebagai-negara-maritim.html. 2014.

[2] S. Pudjiastuti. Indonesian Society Likes to Eat Fish More? http://www.mongabay.co.id/2017/10/19/masyarakat-indonesia-semakinsuka-makan-ikan/. 2017.
[3] Desniar, I. Rusmana, A. Suwanto, and N.R. Mubarik. Screening for Bacteriocin of Lactic Acid Bacteria from Bekasam. Indonesian Fisheries Processing Journal. XIV(2): 124-133. 2011.

[4] Desniar, I. Rusmana, A. Suwanto, and N.R. Mubarik. Antimicrobial Compounds Produced by Lactic Acid Bacteria from Bekasam. Jurnal Akuatika. III(2): 135-145. 2012.

[5] A. Kalista, A. Supriadi, and S.H. Rachmawati. African Sharptooth Catfish Bekasam (Clarias gariepinus) with The Use of Different Carbohydrate Sources. Jurnal Fistech. I(1) : 102-110. 2012.

[6] A. Zummah and P.R.Wikandari. The Effect of Fermentation Time and Addition Starter Cultures of Lactobacillus plantarum B1765 Lactic Acid Bacteria to The Quality of Milkfish (Chanos chanos) Bekasam. Unesa Journal of Chemistry. 2(3): 14-24. 2013.

[7] S. Hadinoto. The Making of Bekasam Cumi-Cumi (Loligo sp) with Variation Salt $(\mathrm{NaCl})$ and Beras Gongseng (Oriza sativa) to Consumer Accepted. Majalah Biam. 9(2): 75-83. 2013.

[8] C. Sriket. Proteases in Fish and Shellfish: Role on Muscle Softening and Prevention. International Food Research Journal. 21(1): 433-445. 2014.

[9] M. Tako, Y. Tamaki, T. Teruya, and Y. Takeda. The Principles of Starch Gelatinization and Retrogradation. Journal of Food and Nutrition Sciences. 5(3): 280-291. 2014.

[10] D. L. E. Waters , R. J. Henry, R. F. Reinke, and M. A. Fitzgerald. Gelatinization Temperature of Rice Explained by Polymorphisms in Starch Synthase. Plant Biotechnology Journal 4(1): 115-122. 2006.

[11] L. Li, F. Shen, R. L. Smith, and X. Qi. Quantitative Chemocatalytic Production of Lactic Acid from Glucose Under Anaerobic Conditions at Room Temperature. Green Chemistry. 19(1): 76-81. 2017.

[12] K. K. F. D. Costa, P. B. Pertuazatti, T. F. de Oliveira, M. Caliari, M. S. S. Junior. Syneresis and Chemical Characteristics of Fermented Rice Extract with Probiotic Bacteria and Waxy Maize Starch. Food Science and Technology. 37(4): 640-646. 2017.

[13] M. M. Nasabi, M. Azadian , A. Farahnaky, and A. R. Yousefi. Comparing the Textural Properties of Surimi and Fish Protein Isolate Gels Produced from Silver Carp. Iran Agricultural Research. 32(1): 110. 2013.

[14] Wisuthiphaet, N., and S. Kongruang. Production of Fish Protein Hydrolysates by Acid and Enzymatic Hydrolysis. Journal of Medical and Bioengineering. 4(6): 466-470. 2015. 